\title{
Environmental impact assessment and environmental management plans: an example of an integrated process from the UK
}

\author{
M. A. Broderick ${ }^{1} \&$ B. Durning ${ }^{2}$ \\ ${ }^{1}$ Halcrow Group Ltd, UK \\ ${ }^{2}$ Oxford Brookes University, $U K$
}

\begin{abstract}
Environmental impact assessment (EIA) is a mature process implemented around the globe to identify significant impacts from development and provide mitigation measures to reduce these impacts. Increasingly in the UK the process is being supplemented through the integration of an environmental management plan (EMP) into the resulting environmental statement. The EMP specifically aims to manage the impacts during the construction phase of the development. This paper presents an example of practice from the UK in this integrated process for the installation of a high pressure natural gas pipeline through open countryside. It demonstrates the added benefit that the integrated process provides in managing and reducing environmental impacts from the development.

Keywords: environmental assessment, environmental management, construction, pipeline.
\end{abstract}

\section{Introduction}

The environmental impact assessment (EIA) process is a well established method used around the globe in the identification and mitigation of the impact of developments on the environment. It consists of a series of studies and discussions which are designed to:

- identify which legislation is relevant to the proposals (screening)

- assess the scope of the project (scoping+consultations) 
- identify the nature of the existing environment (baseline)

- obtain stakeholders views on proposals (consultation)

- identify the impacts of the proposals and predict the likely magnitude and significance of those impacts on the environment (environmental assessment)

- allow the formulation of mitigation measures (mitigation).

The outcome of the process is the production of an environmental statement (ES). Increasingly in the UK the EIA process for developments at varying scales is being supplemented through the integration of a voluntary environmental management plan (EMP) into the resulting ES. The purpose of the EMP is to serve as an operational manual for implementing appropriate environmental controls and monitoring procedures within the construction phase of the proposed development. It sets out to ensure that the construction of the works complies with relevant environmental legislation, licence conditions and accepted good practice and that measures to mitigate impacts discussed in the project ES are implemented.

In this paper we present a case study from the UK of the construction of a high pressure natural gas pipeline, in central southern England, which was subject to the EIA process with a fully integrated EMP (Environmental Resources Management [1]). It is based on the experiences of one of the authors who at the time was employed by consultants Environmental Resources Management (ERM) and undertook the EIA and implementation to the EMP. We aim to demonstrate how the combined process ensures that environmental management procedures during the construction phase limit environmental impacts and ensure that good quality restoration of the pipeline route limits environmental damage, to the extent that eight years later there is very little evidence in the landscape for the presence of the pipeline.

\section{Background to case study}

The pipeline, from Aylesbury in Buckinghamshire to Chalgrove in Oxfordshire, a distance of approximately 26km, was constructed by National Grid (called Transco at the time of pipeline construction in 1999). National Grid is responsible for the operation of the national gas distribution system in Britain known as the National Transmission System (NTS). The NTS transports gas at high pressure along a network of pipelines from the gas production terminals to major gas users ("40 power stations, a small number of large industrial consumers") and a series of "Local Distribution Zones" from which the gas is then distributed at a lower pressure to consumers (National Grid [2]). The case study pipeline was constructed to provide additional capacity for the NTS in order to satisfy an increase in demand for gas in the south of England. It supports an existing pipeline which runs parallel and continues past Chalgrove.

\section{EMP as part EIA process}

The requirement for screening of developments which are possibly subject to the environmental assessment (EA) process has been a requirement in UK law since 
the late 1980s (although the legislation was revised in the late 1990s [3]). Although not all developments are required to go through the process the requirement for high pressure natural gas pipelines falling within certain criteria (length, diameter) to go through the EA process is enacted in specific gas pipeline legislation $[4,5]$. There is no requirement in UK or EU legislation for an EMP to be part of the EIA process. However, it is part of National Grid corporate procedures that an EMP be included in the contract documents on which the commercial terms for the construction contract are negotiated.

\subsection{The EMP process}

The broad purpose of the EMP is to:

- provide a mechanism for ensuring that measures to mitigate potentially adverse environmental impacts are implemented

- ensure that standards of good construction practice are adopted throughout the construction of the pipeline

- provide a framework for mitigating impacts that may be unforeseen or unidentified until construction is underway

To be successful an EMP should evolve throughout the life of the project. For this project the EMP was issued for consultation to various stakeholders and was refined as additional information, design changes or comment from stakeholders becomes available. An EMP can therefore also provide assurance to stakeholders that their requirements, with respect to environmental performance, will be met.

Although the EMP detailed the mechanisms through which the issues outlined above were to be addressed during construction of the pipeline and the responsibilities for meeting them, it was the contractor who was required to provide method statements of the details of the actions to be taken, in order to implement each aspect of the EMP. The method statements had to demonstrate how compliance with the requirements of the EMP were to be achieved, and specify the names of the individual people who will be charged with achieving and monitoring compliance

\subsection{Auditing/monitoring during construction}

The EMP also provided a framework for compliance auditing and monitoring to ensure that its aims are being met. As the EMP formed part of the commercial contract for the contractor during the construction of the pipeline, National Grid required that inspections and audits were undertaken to ensure that the plan was being implemented. In addition to any audits the contractor may undertake, National Grid also commissioned their consultants to undertake periodic site audits. A checklist pro forma was used which covered the environmental issues addressed in the ES and the EMP. Where problems were identified corrective actions were required to be undertaken. These could include further direct mitigation, changes to procedures or additional training. 


\section{Aylesbury-Chalgrove pipeline}

For natural gas pipelines the EIA process can be divided into a series of successive components which mirror the overall engineering design and construction process and also the general approach adopted to EIA for other developments (see Table 1).

Table 1: Overview of environmental, design and construction of pipelines.

\begin{tabular}{|l|l|l|}
\hline $\begin{array}{l}\text { EIA process for natural } \\
\text { gas pipelines }\end{array}$ & $\begin{array}{l}\text { Pipeline design and } \\
\text { construction phases }\end{array}$ & $\begin{array}{l}\text { General approach to } \\
\text { EIA required in UK } \\
\text { legislation }\end{array}$ \\
\hline Establish need & Pre-feasibility & Screening \\
\hline $\begin{array}{l}\text { Route corridor } \\
\text { information study }\end{array}$ & Feasibility & Scoping \\
\hline $\begin{array}{l}\text { EIA (baseline data } \\
\text { collation, impact } \\
\text { prediction) and } \\
\text { production of ES }\end{array}$ & Conceptual design & $\begin{array}{l}\text { EIA (baseline data } \\
\text { collation, impact } \\
\text { prediction) and } \\
\text { production of ES }\end{array}$ \\
\hline Production of EMP & $\begin{array}{l}\text { Detailed design, } \\
\text { commissioning and } \\
\text { construction }\end{array}$ & $\begin{array}{l}\text { Consenting from } \\
\text { Department of Trade \& } \\
\text { Industry }\end{array}$ \\
\hline
\end{tabular}

\subsection{Route corridor information study}

The pipeline route was to be from Aylesbury in Buckinghamshire to Chalgrove in Oxfordshire, a distance of approximately $26 \mathrm{~km}$. The desk based route corridor information study was carried out at the pipeline feasibility study stage and constraint/overlay maps were produced at a scale of 1:50 000, based on:

- geological/ground conditions

- distances

- archaeological sensitivities

- ecological sensitivities

- numbers of roads, rivers, railway, hedgerow crossings

- two route corridors $1 \mathrm{~km}$ wide

The route corridors passed completely through open countryside, in an area known as the Vale of Aylesbury. The topography along the route was gently rolling, although some areas of high ground lay on the fringes of the route. It also passed through a river valley system (River Thame).

The majority of the route corridors was underlain by clay (Jurassic and Cretaceous) with some minor areas of Cretaceous sandstone. Very little superficial deposits occurred along the route and those that were encountered were clay deposits and some floodplain gravels.

The key environmental issues identified from the route corridor study which would require detailed evaluation were: archaeology; ecology and land take. 
Secondary issues which would require consideration, were impact on the landscape and drainage as the land use along the route was agriculture.

\subsection{EIA and production of ES}

The next stage in the process was the undertaking of the EIA, which involved detailed baseline surveys and the collation of the information into an ES where impacts were identified and mitigation measures proposed. Information concerning the project itself, including background, project schedule, construction techniques, restoration and operation were also included. Important information and areas of particular concern were identified and plotted on constraint/overlay maps at a scale of 1:10 000. A preferred route corridor was brought forward for EIA based on distance crossing and avoidance of sensitive areas.

\subsection{Production of an EMP}

The final stage involved the production of the EMP, detailing all environmental constraints along the final route, and the mitigation measures to be taken. It also included detailed restoration practices and highlighted areas where aftercare was necessary, and the nature of the care required. Areas of particular concern were identified and plotted on constraint/overlay maps at a scale of 1:2500. The EMP identified eleven activities which may give rise to potential impacts during the construction of the pipeline and for which mitigation measures were required (ERM [1]). These are reproduced in Table 2.

Table 2: Proposed mitigation to environmental impacts contained within EMP.

\begin{tabular}{|l|l|l|}
\hline Activity & Potential impacts & Proposed mitigation \\
\hline $\begin{array}{l}\text { Pipeline } \\
\text { construction } \\
\text { physical } \\
\text { disruption from } \\
\text { clearance of the } \\
\begin{array}{l}\text { working width, } \\
\text { pipe stores and } \\
\text { temporary } \\
\text { working areas) }\end{array}\end{array}$ & $\begin{array}{l}\text { Damage to significant } \\
\text { ecological, archaeological } \\
\text { sites and species }\end{array}$ & $\begin{array}{l}\text { Will be avoided by: re-routing; } \\
\text { restriction of working width; } \\
\text { bore underneath site; rescue dig } \\
\text { for archaeology; translocate rare } \\
\text { plants; minimise hedgerow } \\
\text { removal and avoid trees; } \\
\text { carefully reinstate topsoil and } \\
\text { habitat }\end{array}$ \\
\hline $\begin{array}{l}\text { Fuel storage } \\
\text { Leakage/ } \\
\text { spillage may give rise to } \\
\text { contamination affecting: } \\
\text { abstraction downstream; } \\
\text { ground-waters; ecology of } \\
\text { surface waters }\end{array}$ & $\begin{array}{l}\text { Site stores located }>50 \mathrm{~m} \text { from } \\
\text { watercourses. Bunded (110\% } \\
\text { capacity) design with } \\
\text { impermeable liners for stores } \\
\text { and refuelling point will be used. } \\
\text { Use drip trays wherever possible. } \\
\text { Provide local first response } \\
\text { absorbents, booms etc. Training } \\
\text { will be given to all staff. Inspect } \\
\text { the works frequently. }\end{array}$ \\
\hline
\end{tabular}


Table 2: $\quad$ Continued.

\begin{tabular}{|c|c|c|}
\hline Activity & Potential impacts & Proposed mitigation \\
\hline & & $\begin{array}{l}\text { Prepare and exercise oil spill } \\
\text { contingency plans. Carry out } \\
\text { regular inspections and } \\
\text { maintenance of plant. }\end{array}$ \\
\hline \multirow[t]{3}{*}{$\begin{array}{l}\text { Machinery } \\
\text { operations }\end{array}$} & Smoke and fumes & $\begin{array}{l}\text { Proper maintenance will be } \\
\text { maintained }\end{array}$ \\
\hline & Noise & $\begin{array}{l}\text { Sitting (pumps, generators etc) } \\
\text { away from dwellings. Provide } \\
\text { adequate silencing. Switch off } \\
\text { when not needed }\end{array}$ \\
\hline & Dust & $\begin{array}{l}\text { Restrict vehicle speeds. Spray in } \\
\text { dry weather }\end{array}$ \\
\hline \multirow[t]{2}{*}{$\begin{array}{l}\text { Construction of } \\
\text { river crossings }\end{array}$} & $\begin{array}{l}\text { Fisheries (migration and } \\
\text { spawning) }\end{array}$ & $\begin{array}{l}\text { Schedule construction activities } \\
\text { to avoid sensitive times or } \\
\text { minimise sedimentation effects. }\end{array}$ \\
\hline & $\begin{array}{l}\text { Stimulation of bank/bed } \\
\text { erosion }\end{array}$ & $\begin{array}{l}\text { Design adequate emplacements } \\
\text { and protection measures. }\end{array}$ \\
\hline \multirow{2}{*}{$\begin{array}{l}\text { Clearance and } \\
\text { activities within } \\
\text { the Right of } \\
\text { Way }\end{array}$} & $\begin{array}{l}\text { Sediment run off to } \\
\text { watercourses, ponds and } \\
\text { lakes }\end{array}$ & $\begin{array}{l}\text { Provision of cut-off drainage and } \\
\text { settlement ponds. }\end{array}$ \\
\hline & $\begin{array}{l}\text { Effects on fish } \\
\text { (asphyxiation; indirect } \\
\text { effects on mitigation and } \\
\text { spawning) }\end{array}$ & $\begin{array}{l}\text { Discharge of pump outlet to soil } \\
\text { surface/crops to promote seepage } \\
\text { (subject to agreement). }\end{array}$ \\
\hline $\begin{array}{l}\text { Waste } \\
\text { management }\end{array}$ & $\begin{array}{l}\text { Contamination of soils } \\
\text { and water from wastes }\end{array}$ & $\begin{array}{l}\text { Effective containment and } \\
\text { management of wastes. }\end{array}$ \\
\hline $\begin{array}{l}\text { External pipe } \\
\text { cleaning }\end{array}$ & $\begin{array}{l}\text { Contamination of soils } \\
\text { and water by blast grits }\end{array}$ & $\begin{array}{l}\text { Use mechanical brushing in lieu } \\
\text { of grit blasting. }\end{array}$ \\
\hline $\begin{array}{l}\text { Machinery } \\
\text { movement } \\
\text { (trafficking) }\end{array}$ & Topsoil compaction & $\begin{array}{l}\text { Strip and segregate topsoil. } \\
\text { Break up panned sections }\end{array}$ \\
\hline \multirow[t]{3}{*}{ Hydrotesting } & $\begin{array}{l}\text { Disruption from } \\
\text { abstraction and disposal of } \\
\text { large volumes of water }\end{array}$ & $\begin{array}{l}\text { Plan and agree abstraction and } \\
\text { discharge points, rates and } \\
\text { contingency arrangements. }\end{array}$ \\
\hline & Pollution from additives & $\begin{array}{l}\text { Minimise/avoid use of dyes, } \\
\text { corrosion inhibitors, oxygen } \\
\text { scavengers }\end{array}$ \\
\hline & $\begin{array}{l}\text { Erosion from failure under } \\
\text { test }\end{array}$ & $\begin{array}{l}\text { Reinstate to pre-erosion } \\
\text { conditions }\end{array}$ \\
\hline $\begin{array}{l}\text { Disruption to } \\
\text { field drains }\end{array}$ & Water-logging/crop losses & $\begin{array}{l}\text { Insert header drains } \\
\text { Reconnect severed drains }\end{array}$ \\
\hline
\end{tabular}

Following completion of the ES and EMP the document was sent to the relevant Government department for approval, as required under relevant 
legislation. They undertook a consultation process with statutory bodies and regulators before granting approval for the pipeline.

1. Receiving material

2. Setting out

3. Pre-construction land drainage

4. Right of way and topsoil stripping

5. Stringing

6. Welding

7. Excavation/trenching

8. Ditching/lowering and lay

9. Tie-ins

10. Bedding and covering pipe

11. Backfilling

12. Reinstatement

13. Post construction land drains

14. Final trim

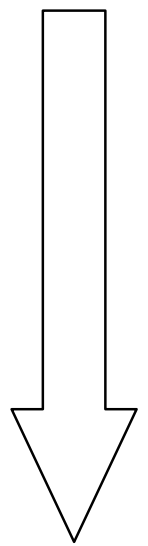

Figure 1: Normal sequence for pipeline construction.

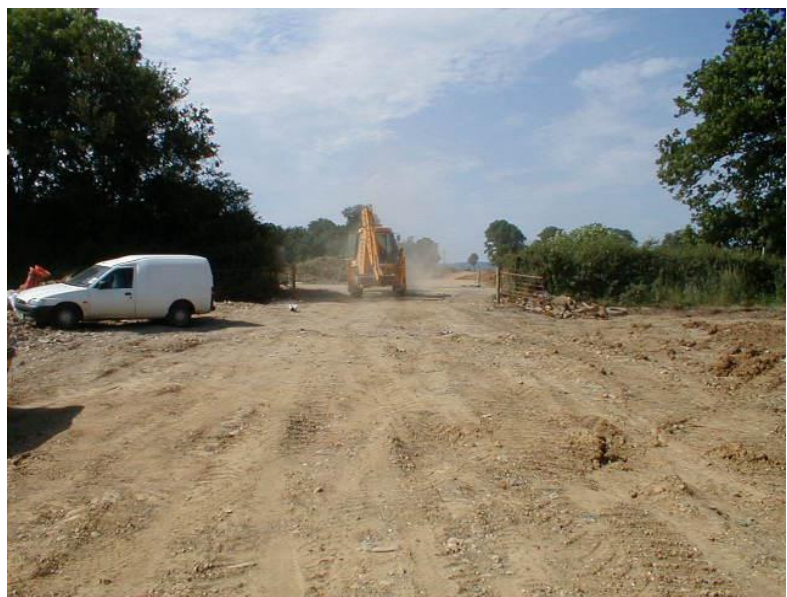

Figure 2: $\quad$ Pipeline route at Stage 4 - excavator is passing over a road and between a gap where hedging has been removed along the field boundary.

\subsection{Construction of pipeline and auditing EMP}

Barnett and Jordin [6] provide a useful guide to the pipeline construction process adapted for the case study. A "spread" method is employed for the construction which "involves several groups of workers and equipment who collectively 
conduct the various stages of the construction operation. Each group completes an activity which picks up where the last one left off, advancing the construction process a step at a time and leaving it ready for the next step to begin". Of note is that fact that construction work is limited to a "seasonal window which extends from March/April to October during which time the weather is more predictable and ground conditions are more favourable". The normal construction sequence is given in Figure 1 (taken from Barnett and Jordin [6])

Auditing during construction of the potentially impacting activities listed in table 2 was carried out regularly by consultants using the methodology referred to in section 3.2.

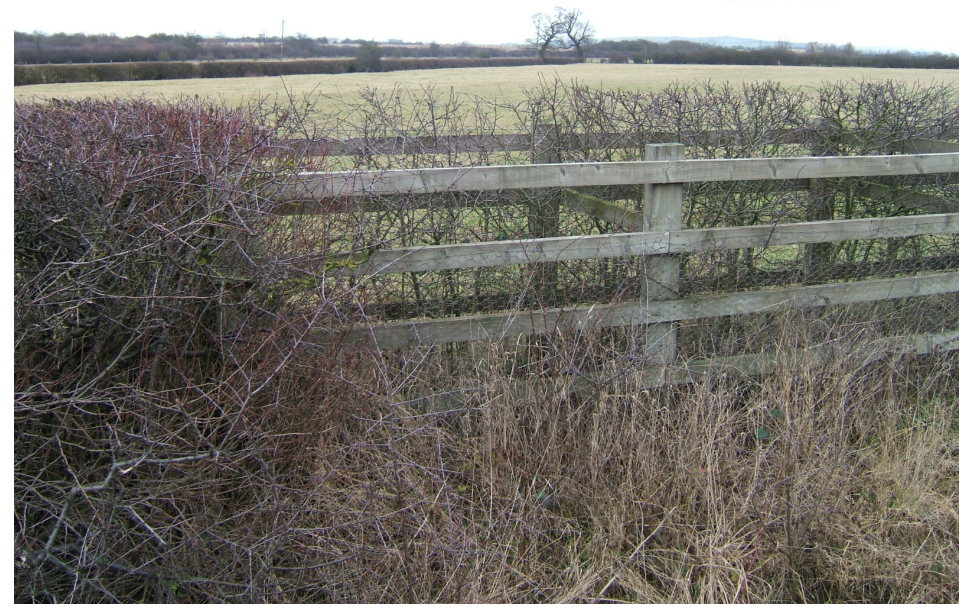

Figure 3: Area of restored hedging and field (taken January 2006 from a road looking along the restored pipeline route).

\subsection{Post construction follow-up}

Due to the national importance of the NTS there is post construction follow up of this development: aerial surveys are regularly employed by National Grid to monitor the route and agriculture liaison officers and land agents maintain regular contact with land owners. In order to assess whether there was any evidence of degradation of the landscape caused by either the pipeline installation or poor restoration a number of points along the pipeline were visited by the authors in January 2006. The points included a road crossing (similar to that in Figure 2), a footpath and a stream crossing. The location of the pipeline was determined by identifying its position on the ES map and locating the National Grid marker post in the nearest road. In all cases very little evidence was found of a legacy of the pipeline. In one field the route could be identified by a darker green swath of grass, suggesting that restoration had improved the 
land quality. The most obvious evidence was in the restored hedging (see example in Figure 3) where the extent of growth is not yet equivalent to that of the hedging removed.

\section{Discussion}

EMPs provide a critical link between EIA and project implementation. In effect EMPs comprise the operational response plan that implements the mitigation and monitoring programs for the project. The execution of an EMP is increasingly becoming conditional to project approval or licensing, and/or to project financing (Equator Principles [7]). The preparation of an EMP acceptable to all stakeholders is therefore a key part of the project development process. Preparing an effective EMP requires a balance between what is desirable, what is affordable, and what can be implemented. In particular it requires:

- all stakeholders to have a common understanding of the objectives of the EMP and particularly to understand the link between the EMP and any approvals or conditions that may be applied to the project on its implementation

- project owners/proponents to have an understanding of the requirements of relevant permitting processes applicable to the EMP and/or be familiar with the needs of specific, relevant financing agencies

- EMP costs to be clearly defined and understood by all parties

- provision to be made for sustainability in implementation of the EMP, particularly in post construction monitoring of impacts.

EMP provides a concrete reassurance that construction/operational impacts identified in the EIA are addressed and mitigated during construction/operation. However, the absence in legislation of a requirement for EMPs and follow up environmental audits is a weakness, a fact which is increasingly being recognised (Morrison-Saunders and Arts [8]). EIA legislation could be strengthened and made more credible if EMPs were mandatory, incorporating environmental auditing during construction/operation.

\section{References}

[1] Environmental Resources Management (1998) Aylesbury to Chalgrove Gas Pipeline: Environmental Review. Report prepared for Transco, UK.

[2] National Grid http://www.nationalgrid.com/uk/Gas/About/ How + Gas + is + Delivered/

[3] Town and Country Planning (Environmental Impact Assessment) (England and Wales) Regulations (1999) SI 293

[4] Gas Act (1995) c 45

[5] Public Gas Transporter Pipe-line Works (Environmental Impact Assessment) Regulations (1999). SI 1672

[6] Barnett, J. and Jordin, M, (1998) Pipelines - a worm's eye view. Transco, Ambergate, UK

[7] Equator Principles http://www.equator-principles.com/principles.shtml 
24 Geo-Environment and Landscape Evolution II

[8] Morrison-Saunders, A. and Arts, J. (2005) Learning from experience: emerging trends in environmental impact assessment follow up. Impact Assessment and Project Appraisal 23 (3) 170-174 